\title{
IMPRESSION OF EMOTIONAL INTELLIGENCE ON IMPULSE BUYING: A CONTEMPORARY FRAMEWORK TO UNERSTANDEMOTIONS IN CONSUMER DECISION MAKING
}

\author{
Sarmistha Nandy \\ Research Scholar
}

\begin{abstract}
Conventional representations of consumer decision-making are mostly cognitive and chronological in nature. Emotional proclamations are made by consumers on a daily basis. Marketer to some extent turns from the conventional marketing schemes. They now concentrate on the role of emotions in the buying procedure. Emotional component plays a vital role in decision making process. Conventional models beliefs emotions are chronological in nature. Generally the negative emotions are dreadful and should be conquer. Attitudes are mainly liable to forecast behavior when cognitive participation is elevated and consumers consider expansively about the information that increases their attitudes. A review of literature on impulse buying, consumer behavior and emotional intelligence is presented and a synopsis of a baseline study on impulse, consumer behavior and emotional intelligence is also presented.
\end{abstract}

Key words - Emotional Intelligence, Impulse Buying, consumer decision-making, emotions, consumer emotional intelligence, ethical marketing.

\section{INTRODUCTION}

Conventional consumer decision making models are ashore on the hypothesis of realistic preferences. At the present time, emotional aspects are important as traditional purposeful features of product/service. Organizations with their promotional activities try to provoke the emotions. Now the term marketing becomes emotional marketing. Boone and Kurtz (2010) explain consumer's activity in the following sequential steps while making a buying decision:

1. They identify the dilemma

2. Consumers hunt for the existing substitutes

3. An estimation of the substitutes arises

4. A buying choice is completed
5. The buying act takes place.

6. A post-purchase appraisal is made

7. Feedback is used in the next consumer decision.

Conventional model is cognitive in nature. Boone and Kurtz (2010) identify some individual manipulation on decision makers. In 1990s marketers started to focus on individual emotions and their function in consumer decision making (Kotler, Kartajaya, \& Setiawan, 2010; Peter \& Olson, 2010). As per Kotler, Kartajaya, \& Setiawan (2010) marketing has moved away from the epoch of forecasting. To highlight the significance of emotions, the authors use quotation of Donald Calne: "The essential difference between emotion and reason is that emotion leads to actions while reason leads to conclusions" (Kotler, et al., 2010, p.170). Marketers occasionally endeavor to manipulate consumer's attitudes by using appeals that bring forth emotions such as adore, craving, delight, anticipate, enthusiasm, panic, annoyance, refusal etc. Positive emotions are proposed to catch the attention of consumers to the offering, while the negative emotions are anticipated to generate concern about will happen if consumers reject the offering. Marketers are now showing interest not only in how emotions are created but also in knowing whether, when and why emotions will forecast buying behavior. Emotions are more strongly connected to behavior when they are easy to get to.

Emotional intelligence is an interesting area of investigation as it overwhelms human way of thinking and disagreement. Emotion often direct numerous decisions and hence its significance. Impulse Buying cascade into this monarchy of emotional intelligence as thirst or wish to acquire something conquers rational way of thinking of the costs implicated or the consequences afterwards in emotional context. On the perspective of broader marketing scenario it has been seen that impulse buying are usually optimistic by marketers. But this impulse buying could have both positive and negative overtone for marketers. Impulse buying is 


\section{International Journal of Engineering Applied Sciences and Technology, 2020 \\ Vol. 5, Issue 7, ISSN No. 2455-2143, Pages 271-274 \\ Published Online November 2020 in IJEAST (http://www.ijeast.com)}

often escorted by negative judgment of fault and grieves. Emotional intelligence is a different psychological capability that can be dependably measured (Brackett \& Mayer, 2003; Mayer, Salovey, Caruso, \& Sitarenions, 2003). Some initial findings imply that inferior EI is associated to involvement in negative outcome (Brackett, \& Mayer, 2003; Trinidad, \& Johnson 2001; Rubin 1999), whereas superior EI is associated with positive outcome (Salovey, Mayer, Caruso, \& Lopes, 2001; Rice 1999; Mayer et al., 1999).

From a theoretical perspective, the study offers an incorporated skeleton on emotional intelligence, and marketing toward an enhanced wide-ranging understanding of the impulse buying behavior of consumer. A literature review on consumer behavior and emotional intelligence is presented and an outline of a baseline study on consumer behavior and emotional intelligence is also presented.

\section{LITERATURE REVIEW}

Since past, many efforts have been made to highlight the emotionalism in diverse fields of knowledge. For Descartes (1649), emotions were a sequence of blind impulse and behaviors different from any emotional practice. There is a huge difference between motivation and emotion just like difference between spirit and body, between indefinable mentality and intelligence. Many philosophers considered the emotions as something that places human beings close to animals.

Charles Darwin (1913) was the first to give strong root for emotions, representing their implication, their adaptive assessment, their effectiveness and statement. Darwin thought that several facial expressions of emotions have an adaptive implication. On the basis of Charles Darwin's hypothesis, the Canadian psychologist Paul Ekman (2007) has established that a significant attribute of basic emotions is that they are collectively uttered, by everyone through similar manner.

Ekman, analyzed how facial expressions act in response to each emotion connecting the similar kind of facial muscles and apart from of prospect, background and traditions.

\section{A. Emotions -}

An emotion is defined a situation of psychological provocation with cognitive features that depend on specific context. There are primary and secondary emotions. Some creators (Ortony and Turner, 1990) believe a diverse number of basic emotions from two therefore positive and negative emotions. Paul Ekman considers annoyance, disgust, panic, happiness, and melancholy as primary emotion while Zamuner (1998) considered happiness, worship, amity, empathy, apprehension, monotony, unhappiness, revelation, panic and annoyance as primary emotions. According to a Robert Plutchik (1997), the primary emotions are eight, divided into four couples: annoyance and panic, unhappiness and happiness, revelation and the waiting, antipathy and approval.

\section{B. Emotional Intelligence -}

Emotional intelligence engages the ability to carry out the interpretation in regard to emotions, and the ability of emotions to improve way of thinking. A numeral interrelated theory exists, including emotional proficiency, emotional creativeness, and sympathetic accurateness (Saarni, 2001; Averill \& Nunley, 1992; Lane, Quinlan, Schwartz, Walker, \& Zeitlin, 1990).

The conception of emotional intelligence, portrayed by Howard Gardner, has been newly developed by Daniel Goleman (1996) with the best seller "Emotional Intelligence: Why It Can Matter More Than IQ". Goleman states that intelligence is only one characteristic of more common skills that facilitate people to react on different situations and to resolve comparative inconvenience.

Goleman's model, as an extensive arrangement of competencies and skills, summarize four primary constructs (Table no. 1):

Table 1: Primary constructs of Goleman's model:

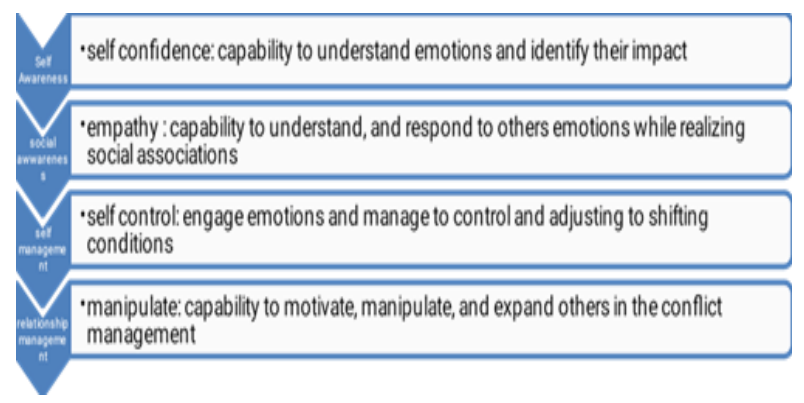

Source: Goleman model, 1996 (adapted by author)

Mayer et al. (2008) confer the following definition of EI: "The ability to perceive emotion, integrate emotion to facilitate thought, understand emotions and to regulate emotions to promote personal growth". The model anticipated from authors contains 4 types of abilities (Table no. 2): description. 


\section{International Journal of Engineering Applied Sciences and Technology, 2020 \\ Vol. 5, Issue 7, ISSN No. 2455-2143, Pages 271-274 \\ Published Online November 2020 in IJEAST (http://www.ijeast.com)}

Table 2: Mayer et al. model

\begin{tabular}{|l|l|}
\hline ABILITIES & EXPECTATIONS \\
\hline Perceiving emotions & $\begin{array}{l}\text { capability to perceive } \\
\text { and decode emotions } \\
\text { in pictures, faces, } \\
\text { tones, and intellectual } \\
\text { artifact }\end{array}$ \\
\hline Using emotions & $\begin{array}{l}\text { capability to connect } \\
\text { emotions to help } \\
\text { different cognitive } \\
\text { deeds, such as } \\
\text { assessment and } \\
\text { problem solving }\end{array}$ \\
\hline $\begin{array}{l}\text { Understanding } \\
\text { emotions }\end{array}$ & $\begin{array}{l}\text { Capability to } \\
\text { understand emotion } \\
\text { idioms and to realize } \\
\text { complex interaction } \\
\text { among emotions. }\end{array}$ \\
\hline Managing emotions & $\begin{array}{l}\text { capability to control } \\
\text { emotions in both } \\
\text { ourselves and in } \\
\text { others }\end{array}$ \\
\hline
\end{tabular}

Source: Mayer model, 2008 (adapted by author)

\section{C. Role of Emotions in Consumer Decision- making -}

Emotion becomes more significant with the appearance of the standard of the consumer contentment. The emotions signify a different form of idiom universally spoken and understood. Emotions are a unique ingredient that must be added to boost the basis supply of product/service. The purchase decisions of consumers are motivated by two kinds of requirements: functional needs fulfilled by product utility and emotional needs related with the psychological aspects of product possession. The creation of emotions usually passes through the multisensory contribution of the subject: melody, aroma, color, flavor, and symbols of various types.

\section{D. Impulse buying -}

Impulse buying could be illustrated as spontaneous and repeatedly uncontrolled advice to purchase products. Modern research on impulse buying (e.g. Verplanken et al 2005) implies that individuals engage in rapid buying mostly due to affective motives.

For that reason, it is significant to recognize the capability of a consumer to:

(a) Make a distinction between emotions;

(b) Employ emotions to direct opinion and behavior. The cognitive behavior helps individuals to think, and act in sensibly based on how they think.

\section{ORIGIN OF CONSUMER EMOTIONAL INTELLIGENCE}

Daniel Goleman in his book "Emotional intelligence" (1995) urbanized the concept of emotional intelligence. Goleman observed there likely to be very modest connection between IQ, as précised by intelligence tests. He established the relation between dissatisfaction, selfconsciousness, perseverance, and understanding with the impulse buying behavior. As per Goleman, emotional intelligence can be trained and person can control their emotions to become best decisionmaker (Cranier, 2006).

\section{A. Realization of consumer emotionalintelligence -}

Mayer-Salovey-Caruso Emotional Intelligence Test (MSCEIT) is an inclusive tool to measure emotional intelligence, developed by Mayor, Salovey, and Caruso (2003). According to Kidwell, Hardesty, and Childers (2008), emotional intelligence include:

a. An individual's level of consumer emotional intelligence (CEI) decides how consumers practice and accomplish emotions in decision-making.

b. Emotional capability forecasts consumer performance beyond the effects of logical knack.

c. Individuals who are incapable to distinguish their emotions were incapable to battle the luxury of renowned brands in spite of their mediocre product qualities.

d. Consumer emotional intelligence is a prognosticator of compulsive depletion.

According to Kidwell et al there is a huge impact of emotional intelligence on consumer impule buying behaviour. As per the findings of Carrera and Oceja (2007), Kotler et al. (2010), and Taylor (2009) emotions can happen along with awareness throughout the decision procedure. Consumer's level of emotional intelligence will also govern how they use negative emotions. It is not impossible to use negative emotions to attain positiveoutcomes.

\section{B. Ethical Implications -}

Ethical implications can come on forth after understanding the role of emotions and emotional intelligence. What marketers think is not so essential but what consumer think is much more essential. Kidwell et al's (2008) research infers that emotional pleas are most operative on those individuals who are least able to practice their emotions to make worthy consumption decisions. According to Goleman (as quoted byCrainer, 2006), emotional intelligence can be erudite. Marketers can play a portion in enlightening consumers about 


\section{International Journal of Engineering Applied Sciences and Technology, 2020 \\ Vol. 5, Issue 7, ISSN No. 2455-2143, Pages 271-274 \\ Published Online November 2020 in IJEAST (http://www.ijeast.com)}

disputes. Using emotions in marketing without honesty is unethical.

\section{REFERENCE}

[1] Albee T., (1977), The Protestant Ethic, Sex and Psychotherapy, American Psychologist.

[2] Baumeister, Roy F., Jennifer D. Campbell, Joachim I. Krueger, and Kathleen D. Vohs (2003), "Does High Self-esteem Cause Better Performance, Interpersonal Success, Happiness, or Healthier Lifestyles ?," Psychological Science in the Public Interest, 4 (May), 1-44.

[3] Beverland M.B., Chung E., \& Kates S.M., (2009), Exploring consumerse conflict styles: Grudges and forgiveness following marketer failure. Advances in Consumer Research, (36), 438-443.

[4] Domenico Consoli, (2009), Emotins That Influence Purchase Decisions And Their Electronic Processing. Annales Universitatis Apulensis Series Oeconomica, 11(2), 996- 1006.

[5] Dr. Deepa Nair, Dr. Saritprava Das (2015). Impact of Emotional Intelligence on Impulse Buying and Product Value Proposition. European Journal of Business and Management. ISSN 2222-1905 (Paper) ISSN 2222-2839(Online) Vol.7, No.1, 165-171.

[6] Gardner H., (1983), Frames of mind, New York: Basic Books.

[7] Gardner H. (1993), Multiple intelligences, New York: Basic Books.

[8] Goleman D., (1998), Working With Emotional Intelligence, Bantam Books.

[9] Hausman A, (2000), A Multidimensional investigation of Consumer Motivation in Impulse Buying Behavior, Journal of Consumer Marketing, Vol. 17.

[10] Holly A. Bell. A Contemporary Framework for Emotions in Consumer Decision- Making: Moving Beyond Traditional Models. International Journal of Business and Social Science Vol. 2 No. 17, 12-15.

[11] Kotler P \& Bes FT, (2003), Lateral Marketing: New Techniques for finding Breakthrough Ideas, Hoboken .N J Wiley\& Sons.

[12] Kotler P., Kartajaya H., \& Setiawan I., (2010), Marketing 3.0: From products to customers to the human spirit. Hoboken, New Jersey: John Wiley \& Sons

[13] Lam S. Y., Vandenbosch M., Hulland J., and Pearce M., 2001, "Evaluating Promotions in
Shopping Environments: Decomposing Sales Response into Attraction, Conversion, and Spending Effects". Marketing Science 20(2), pp.194--215.

[14] Lerner J. S., (2007), Feelings and consumer decision making: Extending the appraisal-tendency framework, Journal of Consumer Psychology, (17)3, 184-187.

[15] Mael F. A., (1991), A conceptual rationale for the domain and attributes of biodata items. Personnel Psychology, 44, 763-792.

[16] Mayer J. D., Roberts R., \& Barsade S.G., (2008), "Human Abilities: Emotional Intelligence," Annual Review of Psychology, 59, 507-536.

[17] Mayer J. D., \& Salovey P., (1997), "What is emotional intelligence," in J. D. Mayer \& D.J. Sluyter (Eds.), Emotional development and emotional intelligence: Educational implications (pp. 3-34), New York: Basicbooks, Inc.

[18] Mayer J. D., Salovey P., \& Caruso D., (2002), Mayer-Salovey-Caruso Emotional Intelligence Test (MSCEIT), Toronto, Ontario: Multi-Health Systems, Inc.

[19] Parboteeah DV, Joseph SV, \& John DN, (2009), The influence of Website, characteristics of a consumer's urge to buy Impulsively, Information Systems Research, Vol.21.

[20] Piron F, (1991), Defining Impulse Purchasing, Advances in Consumer Research, Vol.18.

[21] Rook DW, \& Hoch SJ, (1985), Consuming Impulses, Advances in Consumer Research, Vol. 12.

[22] Rook DW, \& Fisher RJ, (1995), Normative Influences on Impulse Buying Behaviour, Journal of Consumer Research, Vol.22.

[23] Stern H., (1962), The Significance of Impulse Buying Today, Journal of Marketing, Vol.26.

[24] Thorndike E. L., (1920), Intelligence and its uses, Harper's Magazine, 140.

[25] Verplanken Bond, Herabadi A., (2001), Individual Differences in Impulse Buying Tendency feeling and Thinking, European Journal of Personality, Vol.15.

[26] Vohs KD, and Faber R.J, (2007), Spent Resources: Self-Regulatory resource availability affects impulse Buying, Journal of Consumer Research, Vol.33. 